\title{
Protestantism and Government Spending: a Negative Relationship? An Empirical Application to Swiss Cantons
}

\author{
Justina AV Fischer ${ }^{1)}$ and Friedrich Schneider ${ }^{2)}$ \\ Stockholm School of Economics and University of Linz, CESifo
}

SSE/EFI Working Paper Series in Economics and Finance

No 685

December 2007

\begin{abstract}
Recent empirical growth literature suggests that cultural factors play a decisive role in economic development, while empirical evidence for their impact on government activity remains scant. In this paper, we conjecture based on Weber's Protestant Ethics that ,Protestant values' such as self-reliance and austerity should affect both the size and scope of governments. More specifically, we hypothesize that smaller government budgets should be observable in more Protestant jurisdictions. Using a panel of subfederal expenditure in 26 Swiss cantons from 1980 to 1998 we find supporting evidence, observing that the share of Protestants in the cantonal residential population exerts a spending dampening impact. Our results suggest that cultural factors should not be omitted from future public finance analyses.
\end{abstract}

Key Words: Protestantism, Culture, Government Spending, Public Finance

JEL Codes: H72, Z1, A13, H30

1) Corresponding author. Marie Curie Post-Doc Researcher, Department of Economics, Stockholm School of Economics, Sveavegen 65, SE-13383 Stockholm, Sweden, Phone: +4687368962 , e-mail: justina.fischer@hhs.se

2) Professor of Economics, Department of Economics, University of Linz, Altenbergerstraße 69, A4040 Linz, Austria, Phone: +43732/2468/8210, Fax: +43732/2468/8209, e-mail: friedrich.schneider@jku.at 


\section{1) Introduction}

Recent research on the determinants of government spending have set their focus on institutional and political factors, such as, for example, the degree of fiscal decentralization, direct democracy, or political competition (for an overview, see Bjørnskov, Dreher and Fischer, 2007). However, while most of the public finance studies avoid the omission of age-dependent preferences by controlling for age structure of the population, most of them have neglected the influences exerted by culture-specific preferences in the population. ${ }^{1}$ Such culture-determined population preferences might be approximated by observable socio-demographic characteristics such as the ethnic and religious composition of the citizenry (for a justification, see Dorn et al, 2007).

The main goal of our paper is to make an attempt to fill parts of this research gap by analyzing the effects of values relating to Protestant belief systems on government spending, exploiting the variation in religious composition across 26 states/cantons within Switzerland between 1980 and 1998. The federal country Switzerland is particularly suitable for such an analysis as its second-tier government are not only quite autonomous in the public goods' provision (schooling, welfare, health, police), differing in their political institutions and governance structure (see Feld, and Matsusaka, 2003), but also and more importantly, as already noted by Delacroix and Nielsen (2001), vary in the religious composition of their cantonal populations. Moreover, in contrast to those Northern European countries that adopted moderate Lutheranian Protestantism, the type

\footnotetext{
${ }^{1}$ An exception pertains to Schaltegger and Torgler (2006) who investigate the correlation between trust in the governments and their fiscal performance in Swiss cantons.
} 
of Protestantism that was founded and promoted by Calvin (Geneva) and Zwingli (Zurich) in Switzerland was of the extreme type - the type of 'ascetic' Protestantism Weber refers to in his famous work "Die Protestantische Ethik", allowing for an application of his findings. To our knowledge, this paper is one of the first studies to empirically analyze the relation between religion-based values and government spending.

Our empirical results support our hypothesis: they reveal that a larger share of Protestants in the cantonal population leads to less sub-federal government spending. Thus, our results also reveal that omitting culture-driven heterogeneous population preferences in public finance models should be avoided.

The remainder of the paper is organized as follows: Section 2 derives our hypothesis from sociological and economic literature on the nature of Protestant values and their impact on societal development, while the section 3 describes the relevant Swiss data for our empirical analysis. The econometric model is introduced in section 4 , the empirical results of which are presented in section 5. Robustness tests are carried out in sections 6 . Finally, section 7 summarizes and concludes. 


\section{2) Theoretical considerations}

Weber (1930)'s canonical hypothesis of 'Ascetic Protestantism' relates 'Protestantism' to the subjection of human activities to the rationality principle, work discipline of both entrepreneurs and laborers likewise, compliance with business contract due to the abolishment of the institution of 'penance', promotion of literacy, and the replacement of the traditional class system-based 'social elect' with the 'spiritual elect'. All these features serve jointly and separately as explanations for the emergence of modern capitalism and the economic growth that occurred in Northern-European, Protestants cities compared to Southern-European, Catholic cities (Clark, 1951; Frey, 1998; Blum and Dudley, 2001; Delacroix and Nielsen, 2001; Becker and Wössmann, 2007). ${ }^{3}$

In the center of Ascetic Protestantism is the predestination theory and the need for believers to continuously demonstrate through their worldly activities that 'they have been elected', mainly through adherence to a specific life style and morale principles. ${ }^{4}$ Living this ascetic Protestant ethics implies, ceteris paribus, i.e. compared to the behavior of the Catholic counterparts, a more economic profit oriented approach combined with a thriftier attitude, namely not to consume the fruits of one's labor (excess consumption)

\footnotetext{
${ }^{2}$ It is claimed to have facilitated cooperation in a one-shot game setting, i.e. trade with strangers (Blum and Dudley, 2001). The expulsion of Protestants in Catholic-dominated countries contributed to the economic growth gap.

${ }^{3}$ A related strand of literature corroborates the causal relation between broadly defined Protestant values and economic development, both during the contemporary period and the pre- $20^{\text {th }}$ century past (Blum and Dudley, 2001, Granato et al., 1996; Becker and Wössmann, 2007; Cavalcanti et al., 2007) A theoretical growth model with the driving factor being accumulated capital as a measure of piety serving as positional good with externalities to the social norm is developed by Rauscher (1997).

${ }^{4}$ In contrast, Catholics believe that through good deeds good's grace can be 'earned', while such 'transaction' is not possible in a Protestants' world view (Frey, 1998).
} 
but to save or re-invest it. ${ }^{5}$ In consequence, viewing individual (economic) welfare as a signal for 'being chosen' denies any morale obligation to aid persons in need, which would actually constitute an interference with the divine plans. ${ }^{6}$ This Protestants ethics also leads to a devaluation of 'unproductive' and 'uncontrolled', i.e. spontaneity encouraging, leisure activities, in general, and sports and dancing, in particular. ${ }^{7}$ Finally, it also implies a stronger focus on functionality of goods of the daily life that, for example, demands simpler clothing and the abolishment of 'unnecessary' ornaments.

The same way religious values that evolved in the $16^{\text {th }}$ and $17^{\text {th }}$ centuries are shown to influence today's human behavior (e.g. Arruñada, 2004), they may equally shape current population preferences, finally impacting policy outcomes. How would then government spending be affected $?^{8}$ First of all, assuming a strong preference for private savings accumulation, Protestants as defined above should prefer relatively low tax levels. Second, given the cultural heritage of being solely responsible for one own's well-being, Protestants should have a taste for less welfare spending. ${ }^{9}$ As regards overall public goods creation, even if the number of demanded public goods were identical across Protestant and Catholic regions, Protestants should reject anything that could be perceived as an unnecessary luxury, going beyond its pure functionality. Therefore, we conjecture:

\footnotetext{
${ }^{5}$ For empirical evidence using historical data on deposits in savings banks, see Delacroix and Nielsen (2001).

${ }^{6}$ In other words, the poor are not entitled to aid, which does not contradict the moral duty of (voluntary) charity-giving (Frey, 1998).

${ }^{7}$ Historically, protestant Ethics also laid grounds to accepting market competition among sellers, which was originally prevented and hampered by the middle-aged guild system that regulated the production technology and the price of their members (Weingast, 1995).

${ }^{8}$ Barro and McCleary (2003) show that it is religion-based values rather than church attendance rates that matter to economic growth. For an account of the literature demonstrating the strong time-invariance of values related to religion see Dorn et al (2007).

${ }^{9}$ For an empirical linkage between the lesser generosity and broadness of the US welfare systems with the view of the poor as 'lazy' (as opposed to 'misfortunate') and Protestantism, see Alesina et al. (2001).
} 
Hypothesis: Ceteris paribus, the share of Protestants exerts a lowering impact on government spending.

\section{3) Data and descriptive statistics}

Our research question is analyzed using a time-series cross-sectional panel for 26 Swiss cantons from 1980 - 1998, an observational period employed in most empirical studies on government spending in Switzerland (see, e.g., Feld and Kirchgässner, 2001a, 2001b; Feld, Fischer, and Kirchgässner, 2006).

In Switzerland, data on individuals' religious affiliations are collected on a decennial basis in the framework of the Swiss population census. About $90 \%$ of the population appear affiliated which makes it a reliable measure of the distribution of religion-based values. Missing values for the years between the available years 1980, 1990, and 2000 have been linearly extrapolated. In the 26 Swiss cantons, the share of those who profess to be a 'Protestant' varies between about 5\% (Wallis in 1980) and 80\% (Bern 1980) (mean: 30\% and standard deviation: 20\%). In general, cross-sectional variation is substantially greater than the variation within a canton over time. In line with the modernization hypothesis, during the 1980 - 1998 time period, we observe a decline in the maximum share of Protestants from about $80 \%$ down to approximately $70 \%$, and the mean and median, respectively $(34 \% / 35 \%$ to $29 \% / 28 \%){ }^{10}$

\footnotetext{
${ }^{10}$ In the same time period, the minimum share rose from about $5 \%$ (Wallis in 1980) to 8\% (Uri in 1998).
} 
Data on sub-federal expenses, namely combined cantonal and local expenses, were also obtained from the Swiss Federal Statistical office, as were most of the socio-economic controlling variables (share of young ( $<20$ years) and old population ( $>60$ years), degree of urbanization, a dummy that indicates whether the dominating language belongs to the Romance language tree or not). All spending measures have been deflated to the year 1980 and are expressed in per capita values. Descriptive statistics of the dependent variable and the independent variables are reported in Appendix Table A.1.

Turning to simple correlations of the cantonal share of Protestants with overall government spending (both in log-form), the small correlation coefficient suggest that both develop quite independently over time and across cantons $(\rho=0.0226)$. In contrast, in accordance with historical evolution of the Protestant movement, urbanized areas tend to be more Protestant than the countryside $(\rho=0.4595)$. In support of the conjectured preference for 'living a controlled life', Protestants have less children (compared to Catholics) $(\rho=-0.4018)$, but, interestingly, get older $(\rho=0.3308)$, potentially contradicting the view that they work harder than Catholics - at least nowadays they do not seem to 'overwork', degenerating their physical 'capital'. Finally, with a correlation coefficient of $\rho=-0.2437$ Protestants appear rather evenly distributed across the two major Swiss language regions in tri-lingual Switzerland (Romance-speaking (French/Italian) versus German-speaking). 


\section{4) Econometric Model}

Based on traditional public finance models, this paper assumes government spending in canton $i$ at time $t\left(\mathrm{Y}_{\mathrm{it}}\right)$ to be a function of mainly socio-demographic factors. In a second step, further political and economic determinants of government spending are included to test the robustness of this baseline model.

The focal variable is, however, the share of Protestants in a canton (Prot $\mathrm{it}_{\mathrm{i}}$ ). According to our hypothesis, we expect a negative sign for the coefficient $\alpha$. For the substantial correlations among the socio-demographic factors with our variable of interest observed in the raw data (see above), the vector of controlling variables $\mathrm{X}_{\mathrm{it}}$ includes the share of young and old population as well as the degree of urbanization. It also includes a dummy controlling for the main language spoken in a canton to account for ethnic heterogeneity. In the context of public finance, these variables are interpreted as socio-demographic determinants of the demand for government spending (see, e.g. Feld and Matsusaka, 2003). Inclusion of time fixed effects $T_{t}$ completes our model:

$$
Y_{i t}=\alpha \operatorname{Prot}_{i t}+\beta^{\prime} X_{i t}+T_{t}+e_{i t}
$$

Based on previous empirical public finance studies for Swiss cantons, we follow the econometric approach chosen by Kirchgässner and Feld in their various contributions (e.g. 2001a, 2001b), to ensure comparability of their results with ours. ${ }^{11}$ Thus, we employ

\footnotetext{
11 They argue that the inclusion of canton fixed effects is most likely to disguise the impact of (almost) time-invariant factors during the period of investigation. Given that the share of Protestantism does not substantially vary over time, and that missing values have been linearly interpolated, we follow their methodological approach. The de facto time-invariance of Protestantism also justifies assuming its exogeneity.
} 
most of the variables in their log-form, and calculate heteroscedasticity- and serial correlation- efficient OLS estimator with Newey-West standard errors, assuming a twolag correlation structure (AR2 process).

To our knowledge, this analysis is one of the first to view religion-based values as an important determinant of government spending, substantially extending traditional public finance models.

\section{5) Econometric Results}

Table 5.1 presents the results of our analysis. In equation (5.1), as regards the sociodemographic controlling variables, cantons with a larger share of younger residents have significantly lower government spending levels, while the share of old and the degree of urbanization do not appear to matter. ${ }^{12}$ Turning to our variable of interest, the coefficient estimate suggests that the share of Protestants is associated with lower levels of cantonal and local government spending (at the 1 percent significance level). In fact, interpreting the coefficient as point elasticity, an increase in the cantonal share of Protestants by 1 percent is associated with a decrease in government spending by 0.051 percent. Thus, government spending is relatively inelastic to changes in Protestant population preferences, but nevertheless, is responsive in the predicted direction, with an effect larger (in abs. value) than the one of urbanization (-0.051 versus -0.013$).{ }^{13}$ However an elasticity of this size does not necessarily imply that this cultural factor is not of

\footnotetext{
${ }^{12}$ For a similar finding for Swiss cantons with respect to the young population, see Feld and Kirchgässner, 2001 or Feld, Fischer and Kirchgässner, 2006.

${ }^{13}$ The difference is statistically significant at the 5 percent level $\left.(\mathrm{F}(1,470)=3.95)\right)$.
} 
economic importance, as even small changes in the dependent variable may have important implications for the state budget. Indeed, the mean of government spending is our data is about 10,500 Swiss Francs per capita and the mean population about 250,000 inhabitants. Thus, an elasticity of -0.051 implies that an increase in Protestant population by three percentage points would lower government pending by overall 13,230,000 Swiss Francs per year for the average canton.

However, as the share of Protestants is quite substantially correlated with the sociodemographic determinants of sub-federal government spending included in the baseline model, the latter may well serve as socio-demographic transmission channel of Protestants' preferences. For these reasons, the spending effects of Protestants values in the cantonal populations may well be mediated through their socio-demographic composition, a conjecture we test in the following equations 5.2 through 5.4.

Equation (5.2) reports the results when the share of Protestants is interacted with the degree of cantonal urbanization. While the coefficient on the share of Protestants itself turns out significant with a negative sign in this model, supporting our hypothesis of a direct spending lowering partial effect, the negative coefficient on the degree of urbanization itself implies that in cities economies of scale in the provision of public goods are present, a result also reported in other empirical analyses for Swiss sub-federal spending (see e. g. Fischer, Feld and Kirchgässner, 2006). In contrast, the coefficient on the interaction term $(0.024)$ is also highly significant (both at the 1 percent significance level), but with a positive sign. This positive interaction term indicates that the degrees of Protestant values and urbanization aggravate each other, both contributing to higher 
government spending. In consequence, the degree of urbanization appears to mitigate the spending lowering effect of Protestantism,

Thus, the total fiscal impact of Protestantism depends on the values of the urbanization variables which varies substantially in the regression sample (in log-form, min: 0; max: 4.59 , reflecting a variation in urbanization across cantons from $1 \%$ to $99 \%)$,. However, for most degrees of urbanization, the total (marginal) impact of Protestantism appears still spending dampening (at the minimum of $1 \% ;-0.108$, at the mean of $16 \%$ : -0.041). Only for cantons that are urbanized with a degree of $90 \%(\log ($ urban $)=4.5)$, the total marginal impact becomes zero, and thereafter slightly positive. In fact, the only canton with a spending increasing impact is the city canton Basel-city with an urbanization degree of 99\%. However, in this canton the total marginal impact of 'Protestantism' amounts to a value close to zero (0.002). Overall, like in model 5.1, despite a counteracting, namely spending increasing effect exerted by Protestants in more urbanized areas, in total, they still exhibit an expenditure lowering influence.

In equation (5.3), we interact the share of young persons with that of Protestants. While the coefficient on the share of Protestants turns out significant and positive (at the 1 percent level), suggesting a (partial) spending increasing effect, the negative (and significant) interaction term suggests that the total marginal impact (also significant at the 1 percent level) may vary with the socio-demographic composition of the cantonal population. In contrast, we observe no decisive impact of the share of young persons below 20 years per se. 
The calculation of the total marginal impact for different shares of young persons (in log form) in the regression sample shows that for cantons with an average share (and above) the total impact of Protestants is spending dampening (at the mean of 27\%: -0.03; at the maximum of 36\%: -0.14). In contrast, for the minimum fraction of about $17 \%$ the total impact of Protestant values appears even expenditure increasing (0.135). Indeed, the share of young persons at which the total marginal impact of Protestant population preferences is zero is about $24.7 \%$, henceforth becoming negative as their share in the population rises. Thus, in cantons with a relatively young population the society being more adhering to 'Protestant' values appears equally spending lowering, as observed in the original equation (5.1).

Finally, in equation (5.3), we interact our variable of interest with the share of old persons in a canton. However, the insignificant coefficient on the interaction term suggests that the share of old persons does not partially transmit population preferences that relate to having a Protestant world view. In contrast, the coefficient on the share of Protestants is still negative and significant, indicating a spending lowering impact (at the 10 percent level). In consequence, equation (5.3) is in line with the results observed in equation (5.1), supporting a total expenditure restraining influence of 'Protestant' population preferences.

In general, for all equations (5.1.) to (5.4), qualitatively identical findings are obtained in a sample with outlier observations excluded (and normally distributed error terms). ${ }^{14}$ In addition, the results are also robust to the exclusion of single cantons from the regression

\footnotetext{
${ }^{14}$ Outlier observations are identified based on the size of their residuals are excluded (smaller than -2 or larger than 2 standard deviations).
} 
sample. ${ }^{15}$ Overall, assuming exogeneity of de facto time-invariant religious composition of the cantonal populations, we find strong and robust evidence for a spending lowering impact of Protestants values.

\section{6) Further empirical results - robustness tests}

As robustness test, we have tested the sensitivity of our results against other potentially confounding politico-economic factors, that are correlated both with our variable of interest and government spending. Such confounding factors could be income inequality and its redistribution, tax competition, fiscal decentralization, citizen empowerment through direct democracy, fiscal constraints, tax competition, national income and coalition governments.

Based on the Calvinist predestination theory, Protestants may be less inclined to redistribute gross income via taxes and transfers to the needy, compared to Catholics, and may, in distaste of centralized bureaucratic and ecclesiastical control, prefer more decentralized governance structures, namely local decision-making and spending autonomy (Clark, 1951). Moreover, given the propensity to economize, they might have introduced statutory spending constraints to limit government spending, ceteris paribus. For the same reason, the dominance or Protestant values in the population might trigger more wealth compared to more Catholic cantons, ceteris paribus. Finally, Protestants may

\footnotetext{
${ }^{15}$ For equation 5.1, Appendix Table A.2 shows the results of this exercise. A control for Appenzell Ausserrhoden in 1996 which sold their cantonal bank that year turns out insignificant.
} 
prefer larger coalition governments as a consequence of their dislike of being ruled by 'others'.

Based on these thoughts, we test our model against the inclusion of the following variables: effective income redistribution (as measured by the distance between the gross and the post-transfer Gini coefficients), the net income inequality, the degree of cantonal spending decentralization, the strength of direct democratic institutions at the cantonal level (measured by a well known composite index of direct democracy ranging from ' 1 ' to ' 6 '), the presence and power of statutory spending constraints (the measure of which varies from ' 0 ' to ' 4 '), the degree of tax competition between cantons, the level of GDP disaggregated to the cantonal level per cantonal resident, and the number of parties forming a cantonal government (based on an indicator ranging from ' 1 ' to ' 5 '). In general, higher values indicate more influential political institutions. Most of the fiscal variables are obtained from the Federal Tax Administration and the Federal Statistical Office, while the political system-related measures are based on own calculations. These additional controls are widely used in public finance analyses of government spending in Swiss cantons and are described more detailed in, e.g., Feld, Fischer, and Kirchgässner $(2006){ }^{16}$

The results in Table 6.1 show for all model specifications (6.1) through (6.9) that the share of Protestants in the population exerts a significant spending lowering impact, at least at the 10 percent level. The coefficient sizes vary from -0.064 (equation (6.8)) to -0.036 (equation (6.3)). The drop in magnitude (in absolute terms) (and partly in significance levels) observed particularly in equations (6.2) and (6.3) compared to the

\footnotetext{
${ }^{16}$ For a detailed description of the construction of the direct democracy index, see Stutzer (1999).
} 
baseline model estimate of -0.051 (equation (6.1)) suggests that the degree in

Protestantism is (partially) correlated with effective income redistribution and post-tax income inequality. $^{17}$

Most of the additional controlling variables exert an impact that is in line with what common public finance literature suggests: Government expenditure rises with more income redistribution via taxes and transfers, higher post-tax income inequality (reflecting tax base and tax progression effects), and higher national income (equations (6.2), (6.3) and (6.8)). In contrast, government spending is lower in more fiscally decentralized cantons, in more direct democratic cantons, and in cantons with fiercer tax competition (equations (6.4), (6.5), and (6.7)). However, no significant impacts are observable for statutes that aim at balancing the cantonal budget or the size government coalitions (equations (6.6) and (6.9)).

Taken all together, the robustness test of Table 6.1 supports our previous findings that a stronger prevalence of Protestants' values in the cantonal population - as proxied by the cantonal share of persons with Protestant belief - is negatively associated with sub-federal general government spending in Swiss cantons. ${ }^{18}$

\footnotetext{
${ }^{17}$ The actual partial correlations with the (log of the) share of Protestants, conditional on the variables in the baseline model including the time fixed effects, are $\rho=-0.25, \rho=-0.24$, and $\rho=0.28$ respectively. In contrast to expectations, the partial correlation with the (log of) cantonal GDP is only 0.13 .

${ }^{18}$ The spending-lowering impact of the share of Protestants prevails (at least at the 5 percent significance level) if all control variables are simultaneously included in the model in various combinations, even if additionally augmented by population size, ideology of government, and the vertical lumpsum transfers from the federal government to the cantons. These model specifications then quite closely correspond to the public spending regressions estimated in e.g. Feld and Kirchgässner (2001).
} 


\section{7) Conclusion}

Based on Weber's 'Ascetic Protestantism' theory, typical 'Protestant values' are related to catchwords such as 'austerity', 'self-reliance' and 'own responsibility', particularly in comparison with Catholic attitudes, in opposition to which the 'Protestant' movement evolved. This paper addresses the question whether the prevalence of such values in the population restrains costly government activity.

In Switzerland, in which the two dominating religions are Catholicism and Protestantism, we identify for a panel of 26 Swiss cantons between 1980 and 1998 a constraining impact of Protestantism on combined cantonal and local government spending. This effect is robust to taking into account differences in time-variant political factors, economic condition, or potentially correlated governance structures, namely direct democratic institutions and spending decentralization. Moreover, a transmission channel analysis reveals that the socio-demographic composition of the canton in terms of youth and urbanization partly serves as mediating factors. However, the total marginal impact of Protestantism remains consistently negative. Overall, our results show that an increase in the population share of Protestants by 1 percentage point leads to a considerable decrease in government spending by about 1.5 percent, which may amount for the average canton to savings of 150 Swiss Francs per capita or of a total of more than 37 million Swiss Francs.

In consequence, our analysis suggests that population preferences relating to differing value systems should not be omitted from future empirical public finance analyses. In particular, traditional models might well over- or understate the influence of some socio- 
demographic or institutional determinants, potentially leading to a misguided real-life policy prioritization. 


\section{8) References}

Alesina, A., Glaeser E. and B. Sacerdote (2001), Why Doesn't The US Have A European-Style Welfare State?, Harvard Institute of Economic Research, Discussion Paper Number 1933

Arruñada, B. (2004), The Economic Effects of Christian Moralities, Universitat Pompeu Fabra, Economics and Business Working Paper Series 743.

Barro and McCleary (2003), Religion and Economic Growth Across Countries, American Sociological Review 68, pp.778

Becker, S O. and Wössmann, L, (2007), Was Weber Wrong? A Human Capital Theory of Protestant Economic History. Discussion Papers in Economics 1366, University of Munich, Department of Economics

Blum, U., and L. Dudley (2001), Religion and economic growth: was Weber right?. Journal of Evolutionary Economics 11: 207-230.

Clark, S.D. (1951), Religion and Economic Backward Areas, American Economic Review 41, Papers and Proceedings of the $63^{\text {rd }}$ Annual Meeting of the AEA, 258-265.

Bjørnskov, C. Dreher, A. and Fischer, JAV, (2007), The bigger the better? Evidence of the effect of government size on life satisfaction around the world, Public Choice, 127, 267-292.

Delacroix, J and F Nielsen (2001), The Beloved Myth: Protestantism and the Rise of Industrial Capitalism in Nineteenth-Century Europe, Social Forces 80, 509-553.

Cavalcanti, T.V., Parente, S.L., and Rui Zhao (2007), Religion in macroeconomics: a quantitative analysis of Weber's thesis, Economic Theory 32, 105-123. 
Dorn, D., Kirchgässner, G., Fischer, JAV, and A. Sousa-Poza (2007),Direct Democracy and Life Satisfaction Revisited - New Evidence for Switzerland. Forthcoming in Journal of Happiness Studies. DOI: 10.1007/s10902-007-9050-9.

Feld, L.P., and G. Kirchgässner (2001a), The Political Economy of Direct Legislation: Direct Democracy in Local and Regional Decision-Making, Economic Policy 33, 329-367.

Feld, L.P., and G. Kirchgässner (2001b), Does Direct Democracy Reduce Public Debt? Evidence from Swiss Municipalities, Public Choice 109, 347-370.

Feld, L.P., and J.G. Matsusaka (2003), Budget Referendums and Government Spending: Evidence from Swiss Cantons, Journal of Public Economics 87, 2703-2724.

Feld, L.P., Fischer, J.A.V., and G. Kirchgässner, (2006). The Effect of Direct Democracy on Income Redistribution: Evidence for Switzerland, CESifo Working Paper Series CESifo Working Paper No., CESifo GmbH.

Frey, D.E. (1998), Individualist Economic Values and Self-Interest: The Problem in the Puritan Ethic. Journal of Business Ethics 17, 1573-1580.

Granato, J., Inglehart, R., and D. Leblang (1996), The Effect of Cultural Values on Economic Development: Theory, Hypotheses and Some Empirical Tests, American Journal of Political Science 40, 607-631.

Lipset, S.M. (1959), Some Social Requisites of Democracy: Economic Development and Political Legitimacy, The American Political Science Review 53, 69-105.

Paldam, M. (2007), The big pattern of democracy, A study of the Gastil Index, in Democracy, Freedom and Coercion: A Law and Economics Approach, Edited by Alain Marciano and Jean-Michel Josselin. Edward Elgar, Cheltenham, U.K.

Rauscher, M. (1997), Protestant Ethic, Status Seeking, and Economic Growth. ThuenenSeries of Applied Economic Theory, working paper No. 9, University of Rostock. 
Stutzer, A. (1999), Demokratieindizes für die Kantone der Schweiz, IEW Working Paper Nr. 23, Zürich, October.

Weber, M. (1930), The Protestant Ethic and the Sprit of Capitalism, New York: Scribner's, 1930.

Weingast, B.R. (1995), The economic role of political institutions: Market-preserving federalism and economic development, Journal of Law, Economics and Organization $11,1-31$. 


\section{9) Tables}

Table 5.1: Results for the dependent variable - total cantonal expenditure - basic model

\begin{tabular}{|c|c|c|c|c|}
\hline \multirow[b]{2}{*}{ Independent Variable } & \multicolumn{4}{|c|}{ Equation/Estimated coefficient } \\
\hline & 5.1 & 5.2 & 5.3 & 5.4 \\
\hline $\log$ (Prot.) & $\begin{array}{c}-0.051^{\star * \star} \\
{[3.14]}\end{array}$ & $\begin{array}{c}-0.108^{\star * *} \\
{[3.81]}\end{array}$ & $\begin{array}{c}1.222^{\star \star \star} \\
{[2.96]}\end{array}$ & $\begin{array}{c}-0.657^{\star} \\
{[1.76]}\end{array}$ \\
\hline $\log$ (young) & $\begin{array}{c}-1.162^{* * *} \\
{[7.46]}\end{array}$ & $\begin{array}{c}-1.136^{* * *} \\
{[7.39]}\end{array}$ & $\begin{array}{l}0.036 \\
{[0.09]}\end{array}$ & $\begin{array}{c}-1.174^{\star * *} \\
{[7.57]}\end{array}$ \\
\hline $\log ($ old $)$ & $\begin{array}{l}0.101 \\
{[0.87]}\end{array}$ & $\begin{array}{l}0.074 \\
{[0.62]}\end{array}$ & $\begin{array}{l}0.045 \\
{[0.39]}\end{array}$ & $\begin{array}{l}-0.575 \\
{[1.24]}\end{array}$ \\
\hline $\log$ (urban) & $\begin{array}{l}-0.013 \\
{[1.38]}\end{array}$ & $\begin{array}{c}-0.083^{\star * *} \\
{[2.97]}\end{array}$ & $\begin{array}{l}-0.012 \\
{[1.32]}\end{array}$ & $\begin{array}{l}-0.014 \\
{[1.42]}\end{array}$ \\
\hline Dummy for Romance language & $\begin{array}{l}0.098^{\star * *} \\
{[3.89]}\end{array}$ & $\begin{array}{l}0.114^{* * *} \\
{[4.57]}\end{array}$ & $\begin{array}{c}0.118^{* * *} \\
{[4.73]}\end{array}$ & $\begin{array}{c}0.101^{* * *} \\
{[4.04]}\end{array}$ \\
\hline $\log \left(\right.$ Prot..) ${ }^{*} \log$ (urban) & & $\begin{array}{c}0.024^{\star * *} \\
{[2.63]}\end{array}$ & & \\
\hline $\log (\text { Prot. })^{*} \log ($ young) & & & $\begin{array}{c}-0.381^{* * *} \\
{[3.08]}\end{array}$ & \\
\hline $\log (\text { Prot.) })^{*} \log$ (old) & & & & $\begin{array}{l}0.206 \\
{[1.60]}\end{array}$ \\
\hline Constant & $\begin{array}{c}12.862^{* * *} \\
{[15.75]}\end{array}$ & $\begin{array}{c}13.141^{* * *} \\
{[16.28]}\end{array}$ & $\begin{array}{c}9.151^{* * *} \\
{[6.42]} \\
\end{array}$ & $\begin{array}{c}15.030^{* * *} \\
{[9.92]}\end{array}$ \\
\hline \multicolumn{5}{|l|}{ Test Statistics } \\
\hline Observations & 494 & 494 & 494 & 494 \\
\hline F-test & 10.71 & 13.37 & 15.72 & 15.38 \\
\hline (p-value) & 0.000 & 0.000 & 0.000 & 0.000 \\
\hline Adj. R2 & 0.5957 & 0.6082 & 0.6194 & 0.6005 \\
\hline d.f. & 470 & 469 & 469 & 469 \\
\hline
\end{tabular}

Notes: Dependent variable is the per capital total sub-federal expenditure in a canton (in log form). Estimation with OLS and serial correlation and heteroscedasticity consistent Newey-West standard errors. Time fixed effects are included but not reported. *, **, *** denote significance at the 10, 5, and 1 percent level, respectively. 
Table 6.1: Results for the cantonal expenditure per capita - robustness tests

\begin{tabular}{|c|c|c|c|c|c|c|c|c|c|}
\hline \multirow{2}{*}{ Independent Variables } & \multicolumn{9}{|c|}{ Equation/Estimated coefficients } \\
\hline & 6.1 & 6.2 & 6.3 & 6.4 & 6.5 & 6.6 & 6.7 & 6.8 & 6.9 \\
\hline $\log$ (Prot.) & $\begin{array}{c}-0.051^{* * *} \\
{[3.14]}\end{array}$ & $\begin{array}{c}-0.038^{\star *} \\
{[2.13]}\end{array}$ & $\begin{array}{c}-0.036^{\star} \\
{[1.94]}\end{array}$ & $\begin{array}{c}-0.061^{* * *} \\
{[3.94]}\end{array}$ & $\begin{array}{c}-0.049^{* * *} \\
{[2.98]}\end{array}$ & $\begin{array}{c}-0.049^{* * *} \\
{[3.01]}\end{array}$ & $\begin{array}{c}-0.055^{\star * *} \\
{[3.27]}\end{array}$ & $\begin{array}{c}-0.064^{* * *} \\
{[4.55]}\end{array}$ & $\begin{array}{c}-0.059^{* * *} \\
{[3.06]}\end{array}$ \\
\hline $\log$ (young) & $\begin{array}{c}-1.162^{\star \star *} \\
{[7.46]}\end{array}$ & $\begin{array}{c}-0.887^{* * *} \\
{[5.14]}\end{array}$ & $\begin{array}{c}-0.897^{* * *} \\
{[5.24]}\end{array}$ & $\begin{array}{c}-1.098^{* * *} \\
{[7.90]}\end{array}$ & $\begin{array}{c}-1.099 * * * \\
{[7.38]}\end{array}$ & $\begin{array}{c}-1.130^{\star * *} \\
{[7.09]}\end{array}$ & $\begin{array}{c}-1.134^{\star \star *} \\
{[7.43]}\end{array}$ & $\begin{array}{c}-0.408^{\star *} \\
{[2.19]}\end{array}$ & $\begin{array}{c}-1.105^{\text {** }} \\
{[6.84]}\end{array}$ \\
\hline $\log ($ old $)$ & $\begin{array}{l}0.101 \\
{[0.87]}\end{array}$ & $\begin{array}{c}0.332^{\star \star \star} \\
{[2.64]}\end{array}$ & $\begin{array}{c}0.320^{\star \star \star} \\
{[2.64]}\end{array}$ & $\begin{array}{l}0.197^{*} \\
{[1.91]}\end{array}$ & $\begin{array}{l}0.118 \\
{[1.07]}\end{array}$ & $\begin{array}{l}0.105 \\
{[0.90]}\end{array}$ & $\begin{array}{l}0.087 \\
{[0.80]}\end{array}$ & $\begin{array}{c}0.593^{\star * *} \\
{[5.25]}\end{array}$ & $\begin{array}{l}0.124 \\
{[1.04]}\end{array}$ \\
\hline $\log$ (urban) & $\begin{array}{l}-0.013 \\
{[1.38]}\end{array}$ & $\begin{array}{l}-0.013 \\
{[1.14]}\end{array}$ & $\begin{array}{c}-0.014 \\
{[1.15]}\end{array}$ & $\begin{array}{l}0.016 \\
{[1.35]}\end{array}$ & $\begin{array}{c}-0.021^{*} \\
{[1.94]}\end{array}$ & $\begin{array}{c}-0.012 \\
{[1.19]}\end{array}$ & $\begin{array}{l}-0.009 \\
{[0.95]}\end{array}$ & $\begin{array}{r}-0.005 \\
{[0.56]}\end{array}$ & $\begin{array}{l}-0.013 \\
{[1.41]}\end{array}$ \\
\hline Dummy for Romance language & $\begin{array}{c}0.098^{\star * *} \\
{[3.89]}\end{array}$ & $\begin{array}{c}0.145^{\star \star *} \\
{[4.81]}\end{array}$ & $\begin{array}{c}0.135^{\star \star *} \\
{[4.82]}\end{array}$ & $\begin{array}{l}0.033 \\
{[1.09]}\end{array}$ & $\begin{array}{c}0 \\
{[0.01]}\end{array}$ & $\begin{array}{c}0.101^{\star * *} \\
{[4.04]}\end{array}$ & $\begin{array}{l}0.033 \\
{[0.93]}\end{array}$ & $\begin{array}{c}0.151^{* * *} \\
{[6.15]}\end{array}$ & $\begin{array}{c}0.093^{\star * *} \\
{[3.63]}\end{array}$ \\
\hline income redistribution & & $\begin{array}{c}0.241^{* * *} \\
{[3.38]}\end{array}$ & & & & & & & \\
\hline after-tax income inequality & & & $\begin{array}{c}0.024^{* * *} \\
{[3.97]}\end{array}$ & & & & & & \\
\hline Fiscal decentralization & & & & $\begin{array}{c}-0.611^{\star * *} \\
{[3.09]}\end{array}$ & & & & & \\
\hline Direct democracy & & & & & $\begin{array}{c}-0.047^{* * *} \\
{[3.10]}\end{array}$ & & & & \\
\hline Fiscal constraints & & & & & & $\begin{array}{l}-0.009 \\
{[1.41]}\end{array}$ & & & \\
\hline Tax competition & & & & & & & $\begin{array}{c}-0.518^{* * *} \\
{[2.59]}\end{array}$ & & \\
\hline Log (national income) & & & & & & & & $\begin{array}{c}0.502^{* * *} \\
{[6.50]}\end{array}$ & \\
\hline Coalition government & & & & & & & & & $\begin{array}{l}0.019 \\
{[1.36]}\end{array}$ \\
\hline Constant & $\begin{array}{c}12.862^{* * *} \\
{[15.75]}\end{array}$ & $\begin{array}{c}10.942^{\star \star \star} \\
{[11.55]}\end{array}$ & $\begin{array}{c}10.729 * \star * \\
{[11.29]}\end{array}$ & $\begin{array}{c}12.555^{\star \star \star} \\
{[17.64]}\end{array}$ & $\begin{array}{c}12.985^{\star * *} \\
{[16.46]}\end{array}$ & $\begin{array}{c}12.880 * * * \\
{[15.83]}\end{array}$ & $\begin{array}{c}12.954^{* * *} \\
{[17.00]}\end{array}$ & $\begin{array}{c}3.564^{* \star} \\
{[2.24]}\end{array}$ & $\begin{array}{c}12.651^{* * *} \\
{[14.88]}\end{array}$ \\
\hline Test Statistics & & & & & & & & & \\
\hline Observations & 494 & 391 & 391 & 494 & 494 & 494 & 494 & 494 & 494 \\
\hline F-test & 10.71 & 183.40 & 202.45 & 10.44 & 9.81 & 10.71 & 10.29 & 22.52 & 10.46 \\
\hline (p-value) & 0.000 & 0.000 & 0.000 & 0.000 & 0.000 & 0.000 & 0.000 & 0.000 & 0.000 \\
\hline
\end{tabular}


Notes: See table 5.1 


\section{Appendix}

Table A.1: Descriptive statistics

\begin{tabular}{|lrrrrr|}
\hline \multicolumn{1}{r}{ Variable } & Obs. & \multicolumn{1}{c}{ Mean } & Std. Dev. & Min. & Max. \\
\hline & & & & & \\
log (spending) & 494 & 9.24 & 0.23 & 8.82 & 9.86 \\
gov. spending & 494 & 10581.28 & 2610.31 & 6801.75 & 19221.50 \\
log (Prot.) & 494 & 3.18 & 0.81 & 1.60 & 4.35 \\
Prot. & 494 & 31.74 & 20.38 & 4.94 & 77.53 \\
gov. spending & 494 & 10581.28 & 2610.31 & 6801.75 & 19221.50 \\
log (young) & 494 & 3.30 & 0.14 & 2.85 & 3.58 \\
young & 494 & 27.23 & 3.59 & 17.33 & 35.70 \\
log (old) & 494 & 2.95 & 0.12 & 2.62 & 3.30 \\
old & 494 & 19.26 & 2.44 & 13.70 & 27.07 \\
log (urban) & 494 & 2.81 & 1.46 & 0 & 4.59512 \\
urban & 494 & 30.72 & 24.13 & 1 & 99 \\
Romance language & 494 & 0.27 & 0.44 & 0 & 1 \\
income redistribution & 391 & 1.05 & 0.21 & 0.57 & 1.68 \\
after-tax inequality & 391 & 29.18 & 2.30 & 23.53 & 37.81 \\
Fiscal decentralization & 494 & 0.35 & 0.09 & 0.12 & 0.50 \\
Direct democracy & 494 & 4.29 & 1.22 & 1.5 & 5.83 \\
fiscal constraints & 494 & 0.37 & 1.08 & 0 & 4 \\
tax competition & 494 & 0.24 & 0.08 & 0.1 & 0.42 \\
log (national income) & 494 & 10.68 & 0.20 & 10.32 & 11.44 \\
Coalition government & 494 & 3.25 & 0.86 & 1 & 5 \\
\hline
\end{tabular}


Table A2: Exclusion of single cantons from sample for baseline model (equation 5.1)

\begin{tabular}{|c|c|c|c|c|c|}
\hline \multirow{2}{*}{$\begin{array}{l}\text { Excluded } \\
\text { Canton }\end{array}$} & \multicolumn{2}{|c|}{$\begin{array}{l}\text { Estimate for variable of } \\
\text { interest }\end{array}$} & \multirow{2}{*}{$\begin{array}{l}\text { Excluded } \\
\text { Canton }\end{array}$} & \multicolumn{2}{|c|}{$\begin{array}{c}\text { Estimate for variable of } \\
\text { interest }\end{array}$} \\
\hline & $\begin{array}{l}\text { Reduced } \\
\text { sample }\end{array}$ & $\begin{array}{c}\text { Outlier } \\
\text { observations } \\
\text { excluded }\end{array}$ & & $\begin{array}{l}\text { Reduced } \\
\text { sample }\end{array}$ & $\begin{array}{c}\text { Outlier } \\
\text { observations } \\
\text { excluded }\end{array}$ \\
\hline Zurich & $-.052 * * *$ & $-.071 * * *$ & Schaffhausen & $-.046 * * *$ & $-.065 * * *$ \\
\hline Bern & $-.053 * * *$ & $-.074 * * *$ & Appenzell AR & $-.050 * * *$ & $-.067 * * *$ \\
\hline Luzern & $-.054 * * *$ & $-.069 * * *$ & Appenzell IR & $-.056 * * *$ & $-.079 * * *$ \\
\hline Uri & $-.029 * * *$ & $-.057 * * *$ & St. Gallen & $-.051 * * *$ & $-.069 * * *$ \\
\hline Schwyz & $-.064 * * *$ & $-.080 * * *$ & Graubünden & $-.063 * * *$ & $-.073 * * *$ \\
\hline Obwalden & $-.048 * * *$ & $-.059 * * *$ & Aargau & $-.039 * * *$ & $-.057 * * *$ \\
\hline Nidwalden & $-.048 * * *$ & $-.072 * * *$ & Thurgau & $-.045 * * *$ & $-.063 * * *$ \\
\hline Glarus & $-.058 * * *$ & $-.084 * * *$ & Ticino & $-.082 * * *$ & $-.085 * * *$ \\
\hline Zug & $-.046 * * *$ & $-.063 * * *$ & Waadt & $-.050 * * *$ & $-.069 * * *$ \\
\hline Freiburg & $-.049 * * *$ & $-.069 * * *$ & Wallis & $-.052 * * *$ & $-.070 * * *$ \\
\hline Solothurn & $-.050 * * *$ & $-.067 * * *$ & Neuenburg & $-.049 * * *$ & $-.070 * * *$ \\
\hline Basel-City & -.033 & $-.052 * * *$ & Geneva & $-.054 * * *$ & $-.067 * * *$ \\
\hline $\begin{array}{l}\text { Basel- } \\
\text { Country }\end{array}$ & $-.045 * * *$ & $-.064 * * *$ & Jura & $-.050 * * *$ & $-.064 * * *$ \\
\hline
\end{tabular}

Notes: See table 5.2. Reduced sample equals full sample minus one excluded canton. Outlier observations are excluded based on the 1.5 standard deviations of the residuals of the reduced sample. 